\title{
Rochester's rivers, lake, and waste: teaching local environmental history using water case studies
}

\author{
Kristina Chomiak ${ }^{1} \cdot$ David Connell $^{1} \cdot$ Devin Cooley $^{2} \cdot$ Hannah Saxena $^{1}$. \\ Sydney Van Winkle ${ }^{1} \cdot$ Kaitlin Stack Whitney $^{3}$ (D)
}

Received: 21 August 2020 / Accepted: 19 November 2020 / Published online: 10 December 2020

(c) Springer Nature B.V. 2020

\begin{abstract}
In a non-majors upper-level undergraduate environmental history course focused on the Laurentian Great Lakes, students researched and wrote micro-histories of the Rochester, NY area. Many were focused on water-quantity, quality, recreation, and pollution. This article briefly explains the approach and its potential applications to other interdisciplinary water courses. Then five of the original micro-water history cases are presented. It concludes with the lessons learned as a class and for teaching local water history in the future incorporating the previous class' findings.
\end{abstract}

Keywords Great lakes · Case studies · Pedagogy $\cdot$ Pollution $\cdot$ Recreation

\section{Introduction}

Water systems are complex and interdisciplinary, combining social, hydrological and ecological elements. They are also excellent entry points into learning about and conducting original research on local history. Annually, our department teaches an environmental

Kaitlin Stack Whitney

kxwsbi@rit.edu

Kristina Chomiak

kmc5468@ rit.edu

David Connell

davidsamuelconnell@gmail.com

Devin Cooley

cooleydevin@gmail.com

Hannah Saxena

hgs6936@rit.edu

Sydney Van Winkle

srv7357@rit.edu

1 Environmental Sciences Program, Rochester Institute of Technology, Rochester, USA

2 Mechanical Engineering, Rochester Institute of Technology, Rochester, USA

3 Science Technology \& Society Department, Rochester Institute of Technology, Rochester, USA 
history of the Laurentian Great Lakes to civil engineers and environmental scientists. Through a semester-long multidisciplinary research project, they learn the history of the region through a water case study. Here we present the assignment overview and five of the resulting original research cases. They can give insight into pedagogical applications of case study teaching and research using water history to other instructors.

The assignment was to write a short case study of water history in Rochester, NY or the surrounding watershed that drains into Lake Ontario (Appendix 1). The goal was to use water-its presence, its pollution, its controversies - to explore coupled human-nature relationships. Students were required to use primary sources in addition to sources from environmental science, social science, and humanities disciplines. Collectively, our case studies can be read as an application of the iSAW framework (Hale et al. 2015). They incorporate analysis of the water (quantity and quality) with actors (managers, consumers, subsistence fishers, homeowners, beachgoers) and their perceptions and desires, along with both built infrastructure and natural environmental elements. The cases also demonstrate the agency of water itself in the region's environmental history (Foltz 2003); it's not simply an element to be acted upon. We hope that this approach, resulting in both novel local historical research and achieving course learning goals, can serve as a model other courses where water histories are central (Fig. 1).

\section{Lake Ontario water level changes and management: by David Connell, environmental science major and current Masters student in public health}

The water level of Lake Ontario, Rochester's great inland sea, has shifted with time. Lake Ontario has always been an important resource to the people living around it. By the late seventeenth century, the Iroquois had established numerous settlements around the lake as way stations, trading posts, fishing or hunting camps, or strategic defensive encampments (Adams 2008; Konrad 1981). Seneca peoples from villages south of the lake, near modern day Rochester, Victor, Avon, Bloomfield, Mendon, Lima, and the Finger Lakes, traveled to and settled the north shore of Lake Ontario via Irondequoit Bay (Konrad 1981; Donohue 1894). Trade on Lake Ontario swelled as European colonizers arrived, settled, and

Fig. 1 High water levels in Lake Ontario in summer 2018 at the Port of Charlotte in Rochester, NY. Photo credit: Kaitlin Stack Whitney

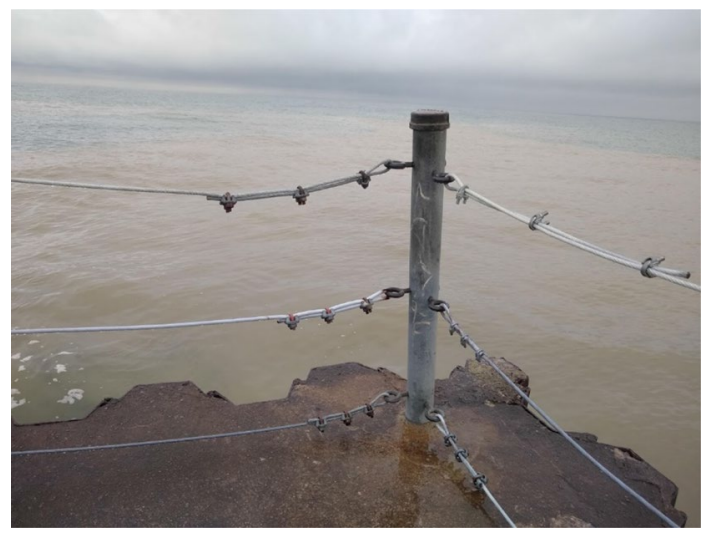


established what are now the United States and Canada. Yet recently there has been much public debate over the management of Lake Ontario's water level by the International Joint Commission (IJC), raising questions about the degree to which human actions affect those natural fluctuations is still in question.

In the mid-twentieth century, the United States and Canada started working on the St. Lawrence Seaway, which built upon the river and existing canals to make a passage between the Great Lakes and the Atlantic Ocean "suitable in all respects for navigation by oceangoing ships", effectively opening up the Great Lakes to international shipping (HR 20189 1917). The two neighboring nations questioned the project's impact on lake water levels from the start, creating the IJC and tasking it in 1920 with answering key questions about the potential project, like the total budget, the optimal route, and deciding "who would maintain, operate, and regulate water levels after completion" (Parham 2009). As more new infrastructure was added to the St. Lawrence in the early twentieth century, flooding disputes began to arise. In the 1950s, American landowners claimed the Canadian-built Gut Dam near Ogdensburg, NY was the cause of record high water levels in Lake Ontario (St. Lawrence Seaway Management Corporation and St. Lawrence Seaway Development Corporation 2020; Gateley 2012). After decades of political turbulence, the Seaway was finally opened in 1959, but the water level issue was not solved. Recently, with so many stakeholders surrounding the lake, the water level issue has become increasingly complex. Waterfront homeowners want the water low to reduce erosion, shippers want the water high to carry cargo, dam operators want maximum flow to keep turbines spinning (Gateley 2012). While the stakeholder differences have existed for decades, the 2017 management changes provide an opportunity to examine historical lake level data and put the modern debate in perspective.

On a geologic time scale, Lake Ontario's water level is highly variable; geologists estimate it was more than $110 \mathrm{~m}$ lower than the current level for a period of about three millennia beginning 13,000 years ago, and it has been rising since (Anderson and Lewis 2012). The current long-term trend is a gradual increase - the lake rose around $10 \mathrm{~m}$ (32 feet) over the last 4000 years. On a more human time scale, the average maximum water level increased by about half of a meter (20 inches) from 1918 to 2010, but in the time period after 1944 (regulation began in the 1950s) variation in extreme water levels decreased significantly (Assani et al. 2014). In other words, regulation stabilized the lake level, as intended, but did not change the long-term trend. Another statistical analysis covering the post-regulation period up to 1999 confirmed that Lake Ontario's water level rose under regulation, but the study attributed the rise to an increase in water supply, not the regulation of flow into the St. Lawrence (Fetzner 1999). 201,460 square miles of land across the U.S. and Canada drain into The Great Lakes Basin (US EPA 2015). That is more area than that of New York, New Jersey, Pennsylvania, Ohio, Indiana, and Vermont combined (US Census Bureau 2019). Water coming from rain, snow melt, runoff, and outflows from groundwater in that massive watershed eventually comes into Lake Ontario. So the key to determining the cause of lake level rise was and is to evaluate whether the lake level acts significantly different relative to the incoming water supply. In the current era of IJC's Plan 2014, scientists concur; a hydrologist advising the IJC said the record-setting lake level rise in early 2017 was due to increased supply from Lake Erie and the other three Great Lakes (Orr 2020). The 2019 high water event, the IJC says, was natural as well. There was "too much water entering Lake Ontario from a flooded Lake Erie, and nowhere for it to go but into a flooded St. Lawrence River" (IJC 2019). This fact is backed up by data from the U.S. Army Corps of Engineers, which shows the water in all the Great Lakes has been well above their long term averages in recent years (US Army Corps of Engineers 2020). 
Finally, it is important to understand how Plan 2014 was developed. To arrive at the new management plan, the IJC commissioned multiple scientific studies over five years. A review of that research found that scientific knowledge of variables affecting Lake Ontario's water level is still inadequate (National Research Council 2006). The authors recommended that the IJC undertake constant study of the Lake Ontario system to continuously improve dynamic models of the watershed. That would be in lieu of the traditional methodology, where the IJC commissions discrete studies when the water management plan becomes inadequate. The authors of this review paper said Plan 2014 will likely be inadequate within years or decades, more research is needed. The IJC established the Great Lakes-St. Lawrence River Adaptive Management (GLAM) Committee for exactly this purpose. The group has consistently churned out reports since 2016 evaluating the hydroclimate of the Great Lakes, measuring water level and flow, and modeling impacts on "commercial navigation, hydropower, municipal and industrial water uses, coastal, recreational boating and tourism" and the environment (GLAM 2020). The IJC is showing this year that it does consider human interests in its decisions: the shipping season the St. Lawrence Seaway was delayed, despite the economic cost, in order to let more water out of Lake Ontario (Orr 2020). Still, it is possible the algorithm itself should weigh infrastructuredamaging outcomes more heavily.

GLAM has expedited a review of IJC deviations from Plan 2014 (like the 2020 shipping season delay) due to the public perception that Plan 2014 is to blame for flooding around Lake Ontario, but that report may not be available until 2021 (Great Lakes-St. Lawrence River Adaptive Management Committee 2020). A second, more comprehensive assessment, has been expedited as well but will take 3-5 years. The ongoing, full evaluation will run through 2032. Residents of Rochester and other shore cities are understandably upset about damage to their properties, but as Susan Peterson Gateley said "unfortunately, natural systems don't always work in simple, predictable ways” (Gateley 2012) (Fig. 2).

Fig. 2 A child trying to catch fish in Lake Ontario in summer 2019 in Ontario Beach Park in Rochester, NY. Photo credit: Kaitlin Stack Whitney

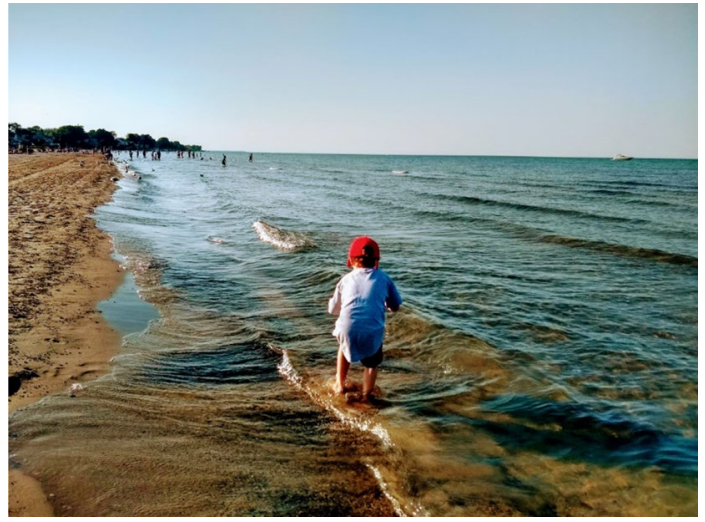




\section{Mirex pollution in Lake Ontario fish and fishers' bodies: by Devin Cooley, mechanical engineering major and current design engineer}

Fishing used to be a large part of the Upstate New York and the Great Lakes region's economic and recreational activity. In the 1800s more fish were taken out of Lake Ontario then are taken out of the lake today (Hudson and Zeigler 2014). This decline in fishing was due to many different factors; one of them is that many of the once cherished fish populations were over fished to collapse, and another is because the fish have become so toxic that people of child bearing age are advised to avoid eating them.

Eating fish out of Lake Ontario has become dangerous to people of all genders due to historical use and production of chemicals in the Great Lakes Water Basin. From 1959 to 1975 the Hooker Chemical Company located on the Niagara River manufactured and processed substantial amounts of the chemical Mirex (Suta 1978). Much of the Mirex that is in Lake Ontario can be linked to the Hooker Chemical Company's discharge during its highest production from 1962 to 1968. Even though Mirex was banned in 1978, it is still showing up in fish that are pulled out of Lake Ontario in 2017 (Makarewicz et al. 2003). This is because chemicals like Mirex have high longevity in ecosystems like Lake Ontario, and unfortunately Mirex could take hundreds of years to completely leave Lake Ontario's ecosystem. When fish eat contaminated food, like other fish and plankton, they store the toxins in their fat cells (Madden and Makarewicz 1996). This continues along becoming more concentrated the higher up the food chain and is the reason why fish in Lake Ontario are full of toxins from the past. Humans, being at the top of the food chain, are exposed to the highest levels of these toxins.

The risks of eating fish from Lake Ontario are higher for child bearing people because of the potential damage to their offspring. This potential damage comes as a direct consequence of ingesting the toxins like Mirex that are in the fish of modern Lake Ontario (Lauber et al. 2017). Local governments are responsible for informing the public on safe consumption levels of fish form Lake Ontario. This information comes in the form of fish advisories. Women tend to be among the highest violators of exceeding fish advisory consumption limits even though they are at the highest risk (Lauber et al. 2017). Chemicals in fish from Lake Ontario are very easily passed to children through breast feeding when the mother consumes them. A study showed that mothers who were breast feeding and consumed well over the fish advisory limits (40lbs or more) were potentially passing significant levels of toxins to their offspring through their breast milk (Lonky et al. 1996). Another study showed that women who ate salmon from the lake potentially passed as high as 2.9 times the safe consumption limits of Mirex, for an adult male, to their infant child (Makarewicz et al. 2003).

One of the main reasons that women of child bearing years exceed the consumption limits is because they are ill-informed of these limits. Only $2 / 3$ of women anglers in the Great Lakes region of child bearing age report knowing and agreeing about fish consumption limits (Connelly et al. 2017). The reason the fish are toxic is because toxic chemicals have been making their way into Lake Ontario for decades. Improved communication may help reduce risk for fish consumption (Fig. 3). 
Fig. 3 The Genesee River in spring 2020, which runs through the city of Rochester and drains into Lake Ontario. Multiple water treatment plants discharge into the river. Photo credit: Kaitlin Stack Whitney

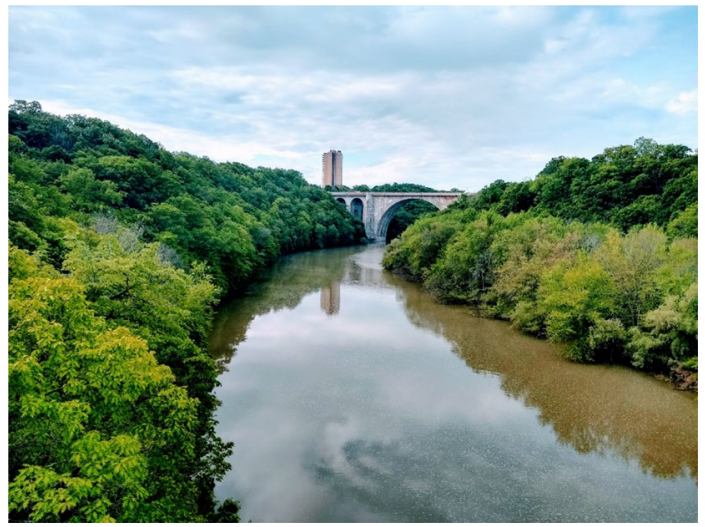

\section{Irondequoit Bay chemistry's impacts on recreation: by Hannah Saxena, environmental science major and current Masters student in environmental science}

Rochester's Irondequoit Bay is a prime recreational spot for the city. The bay includes a beach, restaurants, and recreation activities that make it an ideal tourist spot. Unfortunately, overtime the bay has been degraded, harming tourism to the bay. However, the bay received treatments to improve its water quality and return Irondequoit Bay into a prime tourist location.

Irondequoit Bay has been in a state of eutrophication, which results in problems such as algal blooms, deep sediments of rich organic matter, and an oxygen depleted hypolimnion or bottom strata, during summer stratification. Efforts have been made to reduce this state through the use dredging, aeration, chemical deactivation and sediment sealing. Additionally, internal and external phosphorous loading was a major concern. In 1978, Van Lare Wastewater Treatment facility diverted the external phosphorous loading. Then in 1986, a treatment of aluminum sulfate was applied to the bay to seal the organically rich sediments that were releasing phosphorous through biological degradation. Finally in 1993 and 1994, oxygen diffusers were installed to supply oxygen to the hypolimnion to prevent anoxic conditions and promote the ecosystem to harvest the algal crop preventing biomass from settling to prevent the cycle of biological degradation (Monroe County DES 2016). Since implementing these treatments Monroe County has been monitoring the bay's chemical and physical components to address how these treatments have performed and if new treatments are necessary (Monroe County DES, personal communication and unpublished data).

Recreation in the Great Lakes region is very competitive therefore, these treatments and monitoring methods to improve Irondequoit Bay resulted in an elevated ability to gain revenue from tourism (Chubb 1989). These treatments on Irondequoit Bay have been able to categorize the bay from hypereutrophic to eutrophic, this classification has implications on recreation and tourism of the bay. Researchers have found that improved water quality results in more recreation. Recreational users will travel farther for bodies of water that are clearer and of higher water quality (Keeler et al. 2015). Additionally, amenities accompanying access points to the bay affect the recreational activities there. Access points with beaches, shelters, picnic tables, and food stalls will attract beach goer recreation; while 
angler recreational areas will be those access points with boat ramps, restrooms, and no picnic shelters (Wolf et al. 2019). However, water levels affect the availability of these access points. Due to higher water levels boat launches and other access points have been closed and homes along the bay have flooded or been at serious risk for flooding (Monroe County DES, personal communication and unpublished data). Therefore, the increases in water levels influence recreation (Bergmann-Baker et al. 1995).

In conclusion, Irondequoit Bay has been monitored and treated to improve its water quality and tourism. Treatments were performed using oxygen diffusers, aluminum sulfate treatments, and wastewater treatment. As a result, recreation in the bay has improved but, now water level fluctuations threaten the recreation again. Competitive recreation in the Great Lakes region provides a significant revenues for this area, thus these water level fluctuations that deters tourism is a significant threat that Irondequoit Bay now has to address (Fig. 4).

\section{Durand Eastman Beach Park pollution and beach closures: by Kristina Chomiak, environmental science major and current Masters student in environmental science}

Rochester, New York is home to an abundance of resources, including the terminal Great Lake: Lake Ontario. The lake has proven to be highly valuable to the community as a vital freshwater resource for drinking water and food-and also as a cultural and recreational resource. The location of the lake in close proximity to the city led to the creation of multiple public waterfront parks, such as Durand Eastman Beach Park (DEB), where many residents have benefitted from the calming sounds and scenery and the ability to cool down on a summer day. The park has undergone many changes throughout its history, often driven by changes in the natural environment that impacted recreational usage by the public.

Since its grand opening in 1907, the park has been a popular public space showcasing Lake Ontario. Historically, the waterfront location of the park has impacted the ecology of the area, allowing for diverse plant life to thrive (Coakley and Lewis 2003), and offering a different recreational experience than that of other city parks by including boating and guarded swimming. In fact, the park was so popular that grander infrastructure was constructed, such as the historic bathhouse, a pier, and a trolley line to make the park

Fig. 4 High water levels in Lake Ontario as viewed from Chimney Bluff State Park in winter 2019. Photo credit: Kaitlin Stack Whitney

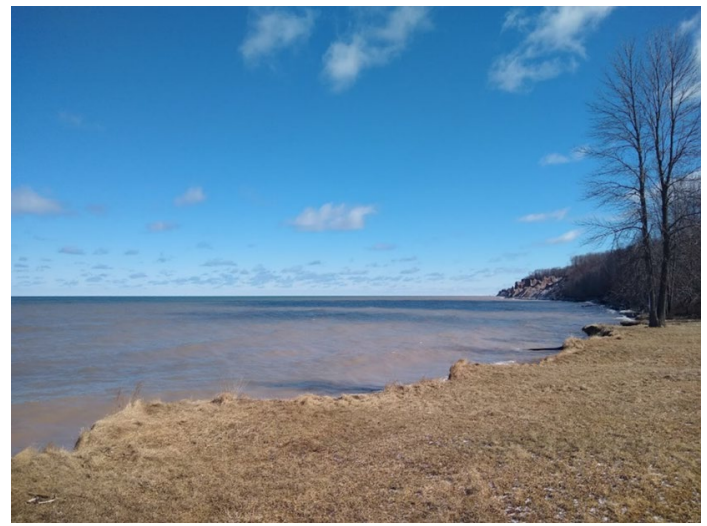


accessible to citizens (Morrell 2015, Rochester DPR 1917). Though these assets are gone now, the addition of a golf course and lodges among the numerous nature trails and scenery has maintained DEB as a valuable source of recreation in Rochester.

By the 1960's, water quality issues led to official closure for swimming. This continued until 2006, when the city reopened a designated area for guarded swimming. Despite reopening, DEB has continued to face water quality issues with high bacteria levels and cyanotoxins. It has been demonstrated that the high phosphorus content "exceeding NYSDEC guidelines" in Lake Ontario has made the lake ideal for nearshore growth of cyanotoxins that pose public health risks upon ingestion (Makarewicz 2006). Water quality issues are also exacerbated by excess discharge released into the water by the Frank E. Van Lare wastewater treatment plant located directly across from the beachfront of the park. The release of nutrients and bacteria such as Escherichia coli from both the treatment plant and nearby streams may be released at higher levels than advised, posing additional public health risks and closures (Orr 2010). Reports from the Department of Environmental Conservation found that excess discharge from the plant occurred as recently as October and November 2017 (NYS DEC 2017).

These water quality issues have led to significant beach closures since Durand's reopening (NYS DEC 2018), disrupting recreation and accessibility. Aside from public health implications, there are also socioecological issues relating to beach closures, as many residents use the free public beach to safely cool down on hot days. Beach closure has been identified by Yardley and researchers as a potential environmental justice issue closely tied to ecosystem health issues from reduced access guarded and safe aquatic recreation (Yardley et al. 2011).

While efforts are ongoing, prioritizing restoration and research into highly used spaces may lead to greater benefits to both ecosystem and public health and enhance accessibility and safety to recreational spaces. Government agencies have acknowledged issues plaguing the Great Lakes, shown by programs like the Great Lakes Restoration Initiative and federal grants to provide long-term solutions (Orr 2010). In guiding restoration efforts, incorporating socioecological factors, such as human usage of an area, to prioritize restoration can increase the local economy generating revenue that can be put back into restoration when benefits of a restored natural environment are seen (Allan et al. 2015). In addition to public recreation, Durand Eastman Park offers lodge rentals

Fig. 5 A retention pond next to the Frank E. Van Lare water treatment plant operated by Monroe County, NY in spring 2020. Photo credit: Kaitlin Stack Whitney

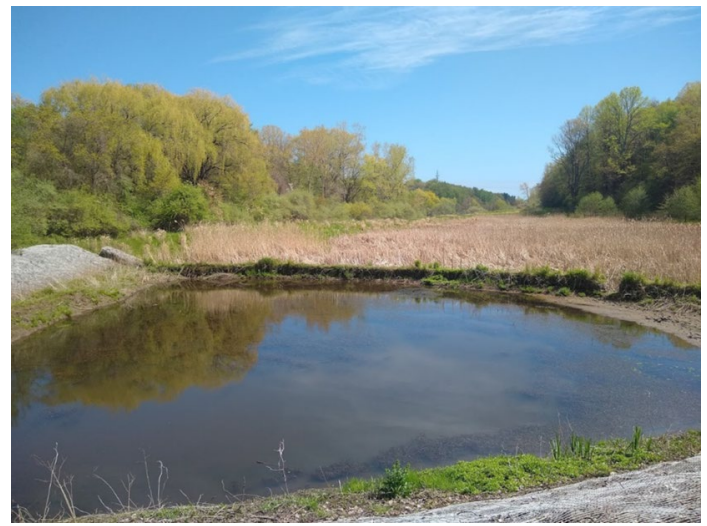


that provides quantifiable data on park usage and a metric for quantifying socioecological benefits of restoration in the community.

Durand Eastman Park and Lake Ontario have provided numerous services, ranging from food and drinking water, to a cultural connection to nature that extend beyond the local community. In the discussion of environmental issues related to this resource, it is critical to acknowledge how environmental changes have impacted societal use, like shifts in recreation and accessibility to nature through time. With DEB's role as a public park, tracking public health and recreational services through history are insightful in understanding the park's historical and modern-day value (Fig. 5).

\section{Waste water treatment and combined sewer overflow systems in Rochester: by Sydney van Winkle, environmental science major and current Masters student in environmental science}

Water pollution control and prevention has historically been a critical issue in the Great Lakes Region, due to the abundant natural freshwater resources. Rochester, NY specifically has long been concerned with the topic of water pollution. In particular, the city in the past 50 years has focused on mitigating contamination from outdated and small sewage facilities throughout the city.

Pollution abatement in New York started in the 1960s due to the fact that the state was being pressured to take responsibility for waste water treatment, monitoring of the freshwater resources, and overall development of research pertaining to water (US Senate Committee on Government Operations 1963). Shortly after this shift in the state, Rochester had its very own Genesee River Waters put on the list as a special class of surface water that should require these kinds of actions associated with it to keep it clean, and ultimately keep Lake Ontario clean as well (US Senate Committee on Government Operations 1963). After Rochester area waters were classified requiring specific standards by the state and by the NYS Water Pollution Control Board, actionable plans were necessary to reduce pollution in the river and in turn Lake Ontario.

During the 1980's residents in the Rochester community were concerned with toxins and pollution coming from Kodak (US Senate Committee on Environment and Public Works 1989). A plea, sent to U.S. Senator Daniel Patrick Moynihan on behalf of all Rochester residents, stated:

We're tired of Kodak's continuous lack and abuse of the law, in regards to the reporting of spills and emissions, tens-of-thousands of untreated chemicals, waste water and sewage, flowing into our historic Genesee River at a time when the Rochester Convention and Tourism Bureau, the Mayor and city leaders, are trying to promote, develop and improve the entire river area. (US Senate Committee on Environment and Public Works 1989).

This concern brought to light the plethora of pollutants that were entering the Genesee River and ground water reserves and shows how invested the people of Rochester were to fix the pollution problem in the area (US Senate Committee on Environment and Public Works 1989). One of the actionable solutions to pollution prevention was continuing with updates to the sewage systems that flowed through Rochester.

Rochester switched to a Combined Sewer Overflow (CSO) system, starting construction in 1982 and concluding in 1991, due to NYS regulating pollution and due to public push in 
the city (Monroe County DES undated). The change in infrastructure, to tackle raw sewage pollution heading directly into the Genesee River, happened through the Combined Sewer Overflow Abatement Program (CSOAP). CSOAP was implemented through Monroe County Pure Waters District federally funded Construction Grants Program of 1980 (Monroe County DES undated). This system was updated to a series of deep tunnels that catch the overflow of the sewers during heavy rain events or wet seasons, instead of it draining directly into the Genesee River or Irondequoit Bay. After the implementation of CSOAP, less sewage entered the Genesee River, and in turn Lake Ontario.

Part of the push for the clean-up of the river area that drained into Lake Ontario was the fact that the people of Rochester valued the water areas for recreation. One of the largest areas of concern impacted by the water flowing out of the Genesee River was, and still is, Durand Eastman Beach park. It once was one of the most popular swimming areas but due to various kinds of bacterial contamination, often linked to the sewer systems and the Genesee River, it has undergone periods of less use (McEntire et al. 2010). The inability to use a beach that has always been a spot for recreation in Rochester helped push forward CSOAP initiatives and has kept the city on track, even now, to plan and budget for water quality planning (Dinolfo 2016). To ensure long-term success for water quality control efforts, long term monitoring now happens from various entities such as Monroe County Water Authority (Monroe County Water Authority 2018). They issue reports annually that outline the "detected substances" at various sampling locations in Lake Ontario, some of which are where the Genesee River enters the lake.

After the past half-century of effort and initiatives like CSOAP, the efforts appear to be working. As of the 2018 report, there were no water quality violations detected, thus indicating the sewage problems and overflow events may be resolved. Monitoring by Monroe County and the local community will carry on, though, with a focus on new contaminants. In recent years, some of the main concerns to researchers interested in the river and the lake are phosphorus and sediment loading (Makarewicz et al 2015). Though this may differ from what originally peaked the interest in the pollution of the freshwater resources in and around Rochester, the investigation of potential pollutants and maintenance of clean water has remained critical.

\section{Conclusion}

The five micro-histories we present here are tied together not merely by being in the same watershed - their actors and interests intersect in ways that illuminate the value of focusing on water to understand the past and imagine the future. Beyond allowing students to explore their personal interests in the region in depth, they learned larger historical lessons by reflecting on the connections between their case research at the end of the semester. Students have reflected that conducting original research on local water history helped them understand how past individual choices and collective infrastructure shapes science and engineering in the present. Further, this allows them to think about the opportunities and constraints that these choices may mean for the future of the city and its waterways. Additionally, students who come from fields most familiar with quantitative data get experience exploring qualitative sources as evidence, often combining both types of data to build their essay. This is a vital skill, as many students in the course are environmental scientists and engineers, who will go on to work on interdisciplinary teams to address environmental problems that will require respecting and incorporating disparate kinds of expertise.

After four years of running this project, including during the COVID-19 pandemic in fall 2020, several updates have improved the experience for classes. One is to develop and 
maintain a list of archives and collections, including digital and digitized collections, which may be useful for students' projects. Digital options have been especially important during the pandemic, due to restrictions on fieldtrips and collections, as well as accommodating the needs of high-risk students. Additionally, many students are more comfortable with digital research tools, as most students in the course come from disciplines that have never required they physically access a museum or archive. Another is to intentionally weave a diversity of types of primary sources, including music and other art, into the course lecture materials. Demonstrating the wide range of potential primary and archival materials, including fiction, that can be used as evidence in class by the instructor helped students reflect on the many ways they can tell their own story. And finally, carve out time in the semester for students to share their micro-histories with each other. This includes end of semester sharing, whether in class or asynchronously online, of final drafts. Peer review of drafts in progress, using structured review questions (Appendix 2), has also helped students reflect on their own essays in progress and constructively push each other's work forward. While each case illuminates an aspect of Rochester's environmental history, when shared, the class sees new connections between their research and others' work, furthering the assignment and course goals of analysis and synthesis through local history research.

Author contributions KSW devised the project. All authors wrote and revised the manuscript.

Funding Not applicable.

\section{Appendix 1: Rochester micro-environmental history essay assignment outline}

Goal: The goal of the semester essay is to explore the environmental history and coupled human-nature relationships related to the city of Rochester and surrounding nearby areas.

\section{Why is this our semester project?}

Several of the course objectives include writing about environmental challenges in the Great Lakes using social science and humanities evidence. These include exhibiting social science literature review skills, demonstrating social science and humanities field skills (that's where using a primary source comes in!), and using technical writing skills to explore human-natural interactions in the Great Lakes basin.

Deliverables: To get full credit on the final, you must submit the following 3 items and they must adhere to the guidelines explained in this document.

- Completed essay

- Annotated bibliography

- Author bio

\section{Complete Essay guidelines:}

- Structure: Introduction, 3-4 Body Paragraphs of Evidence and Arguments, Conclusion

- Clear thesis statement

- Clear ties to Rochester region 
- Essay makes clear case for a coupled human-natural systems dynamic

- Strong narrative arc and transitions between ideas/paragraphs

\section{Annotated Bibliography guidelines:}

The annotated bibliography should be an annotated list of at least 6 sources (can be more) that you will use to analyze and discuss your topic. Annotations should at least four sentences, briefly describing the source and how it will help you understand your topic. Basically, as you read and after you have read a source, it's your notes on the source to refer back to as you organize your outline and write your essay later.

\section{Source requirements:}

At least two-thirds of your sources should be from the social sciences or humanities - helping you understand the social context and consequences of your topic. At least 2 of your sources must be a primary or archival source.

\section{Appendix 2: Rochester micro-environmental history peer review template}

Your name:

Name of person whose work you are reviewing:

What's at least one thing you really enjoyed about their essay?

What did you learn that was new to you?

Is the topic of the essay at the intersection of science and society?

Is the connection to Rochester clear?

Is the thesis of the essay clear?

If not, explain why and suggest ways to potentially make the objective(s) more clear.

Are the arguments in the essay well-reasoned and appropriately explained?

If not, explain why and offer suggestions.

Does the essay have at least the minimum number of sources required?

Are at least two-thirds of those from humanities and social science sources?

Are at least two sources from primary or archival records?

Does the annotated bibliography help you understand what each source was about?

If not, explain why.

Can you clearly see the connection between the sources/annotations and the arguments in the essay?

If not, explain what you think is missing.

\section{References}

Allan, D., Smith, S., McIntyre, P., Joseph, C., Dickinson, C., Marino, A., Biel, R., Olson, J., Doran, P., Rutherford, E., Adkins, J., Adeyemo, A. "Using cultural ecosystem services to inform restoration priorities in the Laurentian Great Lakes." Frontiers in Ecology and the Environment 13, no. 8 (2015)

Anderson TW, Lewis CFM (2012) A New Water-Level History for Lake Ontario Basin: Evidence for a Climate-Driven Early Holocene Lowstand. J Paleolimnol 47(3):513-530. https://doi.org/10.1007/s1093 3-011-9551-8 
Assani AA, Landry R, Biron S, Frenette J-J (2014) Analysis of the Interannual Variability of Annual Daily Extreme Water Levels in the St Lawrence River and Lake Ontario from 1918 to 2010. Hydrol Process 28(13):4011-4022. https://doi.org/10.1002/hyp.9941

Bergmann-Baker U, Brotton J, Wall G (1995) Socio-Economic Impacts of Fluctuating Water Levels on Recreational Boating in the Great Lakes. Canadian Water Resources Journal 20(3):185-194. https://doi. org/10.4296/cwrj2003185

“Canada and United States: Lake Ontario (Gut Dam) Claims Arbitration Agreement." International Legal Materials 4, no. 3 (1965): 468-77. https://www.jstor.org/stable/20689919.

Chubb, Michael (1989) "Tourism Patterns and Determinants in the Great Lakes Region: Populations , Resources , Roads , and Perceptions.” GeoJournal 19(3): 297-302. https://www.jstor.org/stable/41144 930.

Coakley JP, Lewis CFM (2003) Sedimentary environment of lake Ontario: geologic setting, sediment processes, and related environmental issues. Michigan State University Press: Aquatic Ecosystem Health \& Mgmt Soc, pp 59-96

Connelly NA, Lauber BT, Niederdeppe J, Knuth BA (2017) Are women anglers of childbearing age in the great lakes region following fish consumption guidelines? J Great Lakes Res 43:187-191

County of Monroe New York State Department of Environmental Services. Undated. Wastewater: Collection and Treatment by Monroe County-Operated Facilities. 1-18. https://www.monroecoun ty.gov/File/DES/Wastewater\%20-\%20Collection\%20and\%20Treatment\%20by\%20Monroe\%20Cou nty-Operated $\% 20$ Facilites.pdf

Dinolfo C, New York State County of Monroe (2016, February). 2017-2022 Capital Improvement Program. Rochester, NY. https://www2.monroecounty.gov/files/1722\%20CIP\%20report\%20to\%20 MCPB.pdf

Donohoe T (1894) The Iroquois and the Jesuits: the story of the labors of catholic missionaries among these Indians. Buffalo Catholic Publication Company, 1894.

Fetzner M (1999) Statistical analysis of lake Ontario Water Levels. Theses, January 1, 1999. https:// scholarworks.rit.edu/theses/7373.

Foltz RC (2003) Does nature have historical agency? World history, environmental history, and how historians can help save the planet. The History Teacher, Vol. 37, No. 1, Special Feature Issue: Environmental History and National History Day 2003 Prize Essays (Nov., 2003), pp. 9-28.

Gateley SP (2012) Maritime tales of lake Ontario. The History Press, Charleston

Great Lakes-St. Lawrence River Adaptive Management Committee (2020) Annual work plan 2020. International Joint Commission, 26 Feb, 2020. https://ijc.org/en/glam/annual-work-plan-2020.

Hale RL et al (2015) iSAW: integrating structure, actors, and water to study socio-hydro-ecological systems, Earth's. Future 3:110-132. https://doi.org/10.1002/2014EF000295

H.R. 20189 (1917) An Act Making appropriations for the construction, repair, and preservation of certain public works on rivers and harbors, and for other purposes. Public Law 36. U.S. Statutes at Large 65:250-270. https://www.loc.gov/law/help/statutes-at-large/63rd-congress/session-3/c63s3ch142.pdf

Hudson JC, Ziegler SS (2014) Environment, culture, and the Great Lakes fisheries. Geogr Rev 104(4):391-413

International Joint Commission (2019) Causes of the 2019 high water event. Accessed Dec 17, 2019. https://ijc.org/en/loslrb/watershed/causes-2019-high-water-event.

Keeler BL, Wood SA, Polasky S, Kling C, Filstrup CT, Downing JA (2015) Recreational demand for clean water: evidence from geotagged photographs by visitors to lakes. Front Ecol Environ 13(2):76-81. https://doi.org/10.1890/140124

Konrad V (1981) An iroquois frontier: the north shore of Lake Ontario during the late seventeenth century. J Hist Geogr 7(2):129-144. https://doi.org/10.1016/0305-7488(81)90116-X

Lauber BT, Connelly NA, Knuth BA (2017) Urban anglers' adherence to fish consumption advisories in the Great Lakes region. J Great Lakes Res 43:180-186

Lonky E, Reihman J, Darvell T, Mather Sr MJ, Daly H (1996) Neonatal behavioral assessment scale performance in humans influenced by maternal consumption of environmentally contaminated Lake Ontario fish. J Great Lakes Res 22(2):198-212

Madden AB, Makarewicz JC (1996) Salmonine consumption as a source of Mirex in human breast milk near Rochester, New York. J Great Lakes Res 22(4):810-817

Makarewicz JC (2006) The occurrence of cyanotoxins in the Nearshore and coastal embayments of lake Ontario. Studies on water resources of New York and the Great Lakes. The State University of New York, Brockport

Makarewicz JC, Damaske E, Lewis TW, Merner M (2003) Trend analysis reveals a recent reduction in mirex concentrations in coho (OncorhynchusKisutch) and Chinook (O. Tshawytscha) Salmon from Lake Ontario. Environ Sci Technol 37(8):1521-1527 
Makarewicz JC, Winslow TW, Rea E (2015) Utilizing intensive monitoring and simulations for identifying sources of phosphorus and sediment and for directing, siting, and assessing BMPs: the Genesee river example. J Great Lakes Res 41:743-759. https://doi.org/10.1016/j.jglr.2015.06.00

McEntire M, Reese F, Cuningham E (2010) Durand Eastman Beach: Back and Better than Ever. Clearwater: Water Quality Improvements in the Genesee Valley, 40, 29-31.

Monroe County (2020) Durand Eastman Park. Accessed 8 April, 2020. https://www2.monroecoun ty.gov/parks-durandeastman.php

Monroe County Department of Environmental Services (2016) Irondequoit Bay Monitoring Report 2015

Monroe County Water Authority, Monroe County. (2018) 2018 Annual Water Quality Report. Rochester, NY. https://www.mcwa.com/Portals/0/PDF/2018_MCWA_AWQR.pdf

Morrell A (2015) Durand-eastman bathhouse. Rochester Democrat and Chronicle, 24 May 2015:16

National Research Council (2006) Review of the Lake Ontario-St Lawrence River Studies. The National Academies Press, Washington

NYS Department of Environmental Conservation (2018) Rochester embayment area of concern: beach closings, beneficial use impairment removal report. NYSDEC, Albany, NY

NYS Department of Environmental Conservation (2020) Sewage discharge reports. Albany, NY: NYSDEC, 2017. Accessed April 8, 2020.

Orr S (2010) Grant will help clean up water at Durand-Eastman beach. Rochester Democrat and Chronicle, 24 November 2010.

Orr S (2020) High winds, high water, lots of hot air: facts and fiction about lake Ontario's Plan 2014. Rochester Democrat and Chronicle. Accessed March 6, 2020.

Orr S (2020) Lake Ontario's High Water Prompts Delay in Shipping Season until April 1. Rochester Democrat and Chronicle. Accessed April 15, 2020.

Parham CP (2009) The St Lawrence seaway and power project: an oral history of the greatest construction show on earth. Syracuse University Press, Syracuse. https://doi.org/10.2307/j.ctt1j5d5bc

Rochester Department of Parks (1917) The 1917 report. Historic Serials Collection, Rochester, New York

Suta BE (1978) Human population exposure to Mirex and Kepone. Environmental Protection Agency, Office of Research and Development, pp 17-19

The St. Lawrence Seaway Management Corporation, and Saint Lawrence Seaway Development Corporation (2020) The St. Lawrence Seaway: A Vital Waterway. Great Lakes St. Lawrence Seaway System. Accessed 15 April, 2020. https://greatlakes-seaway.com/en/the-seaway/.

United States Army Corps of Engineers (2020) Great lakes water level data. https://www.lre.usace.army.mil/ Missions/Great-Lakes-Information/Great-Lakes-Information-2/Water-Level-Data/.

United States Census Bureau (2019) TIGER/Line Shapefiles, 2019. https://www.census.gov/geographies/ mapping-files/time-series/geo/tiger-line-file.html.

U.S. Congress. Senate. Committee on Environment and Public Works (1989) Toxic materials handling at industrial facilities in the Rochester, NY area: hearing before the Subcommittee on Environmental Protection of the Committee on Environment and Public Works. 101st Cong., 1st sess., March 21st, 1989 (statement of Richard C. Streeter III)

U.S. Congress. Senate. Committee on Government Operations (1963) Water pollution control and abatement: hearings before a subcommittee of the Committee on Government Operations, House of Representatives, 88th Cong., 1st sess., August 9th 1963 (New York Water Pollution Control Board)

United States Environmental Protection Agency (2015) Physical features of the great lakes. Data and Tools, September 16, 2015. Great Lakes. https://www.epa.gov/greatlakes/physical-features-great-lakes.

Wolf D, Chen W, Gopalakrishnan S, Haab T, Allen Klaiber H (2019) The impacts of harmful algal blooms and $E$. coli on recreational behavior in lake erie. Land Econ 95(4):455-72. http://le.uwpress.org

Yardley J, Sigal RJ, Kenny GP (2011) Heat health planning: the importance of social and community factors. Global Environ Change 21(2):670-679

Publisher's Note Springer Nature remains neutral with regard to jurisdictional claims in published maps and institutional affiliations.

Kristina Chomiak is a graduate student in environmental science at the Rochester Institute of Technology.

David Connell is a graduate student, now at UC Berkeley, who recently graduated from the Rochester Institute of Technology. 
Devin Cooley is an engineer and recent graduate in mechanical engineering from the Rochester Institute of Technology.

Hannah Saxena is a graduate student in environmental science at the Rochester Institute of Technology.

Sydney Van Winkle is a graduate student in environmental science at the Rochester Institute of Technology.

Kaitlin Stack Whitney is an assistant professor in the Science, Technology, and Society department at the Rochester Institute of Technology. Trained in both STS and ecology, her research focuses on human-insect entanglements in novel ecosystems. She teaches a 'Great Lakes' environmental history course annually for non-history majors, mostly environmental science and civil engineering students. 